\title{
National Girl Child Day: Save Girl Child and Educate Her (Guest Editorial)
}

National girl child day is celebrated every year on $24^{\text {th }}$ of January. The Ministry of Women and Child Development, Government of India initiated this celebration in 2008. This celebration was started to offer more supports and new opportunities to the girls in the country. It aims at highlighting the inequalities such as inequality in education, nutrition, legal rights, medical care, protection, honour, and child marriage, faced by a majority of the girls in the country and also to promote awareness about rights that every girl in India is entitled to.

Girls in India face discrimination from cradle to grave in different forms and in different arenas of life. There are several institutions (Government and nongovernment) that are attempting to bring in changes in the practices related with the discrimination against the Girl Child in India. Discrimination against the Girl Child is a very serious social problem prevailing in our country.

It is a matter of serious concern that demographically the child sex ratio [CSR], a measure of females (943) per 1000 males, has been progressively declining in each decade of census since 1901 to 2011. Despite a plethora of summits, conferences and events held for promoting gender equality, unborn female foetuses continue to be killed in the womb itself or female infants dumped as garbage. If it continues, it will further aggravate the gender imbalance in the society. India has witnessed gender inequality from its early history due to its social, economic and religious practices that resulted a wide gap between the position of men and women in the society. Men and women are the two halves of humanity who need equal support and cooperation and without the one; another one cannot reach up to the excellence.

The National Day of Girls helps raise awareness not only of the issues that girls face, but also of what is likely to happen when those problems are solved. For example, educating girls helps reduce the rate of child marriage, disease and helps strengthen the economy. Educating women is the prime factor to combat gender discrimination and for the upliftment of women.
The Government of India has taken several measures and also making endeavourer to hoist the status of women in the society in order to promote equality of men and women. The different plans, programmes, and policies have laid emphasis on women empowerment and raising the economic, educational, health and political participation of women to match with that of men. The draft national policy on empowerment of women envisages 1) to setup councils at the national and State levels to review the implementation of the recommendations of the national and State Commissions for women. 2) The centre and State to draw up time bound action plans to translate this policy into concrete action in consultation with the Central and State Commissions for women. (3) Every ministry at the Centre and the State is obliged ensure equal flow of benefits in physical and financial terms to all the women.

Although efforts and resources have been invested by different change agents and little awareness has been generated about the social evil, a lot is still to be done. First of all, there is a lack of a nationalised awareness campaign that can bring about sustained behavioural change. Sporadic awareness campaigns have been undertaken but they are disconnected. There is a burning need for a systematic social change campaign. A social change campaign can help modify and abandon attitudes, beliefs and practices of preference for a son at the time of birth. For a focused approach it is important to identify all bodies involved as the change agents and target adopters. Effectiveness and appropriateness is a major concern regarding all central and state government schemes. Most of these schemes are targeted towards the rural and the urban population. Urban middle and rich classes stand to gain little from these schemes and therefore they fail to address the objective. Effectiveness of the scheme with respect to the benefit of the scheme reaching the targeted population is an issue. Private players, NGO and the government together must develop a program.

In particular, the elected representatives in villages/towns, State Assemblies and country's Parliament and Rajya Sabha have to assume added 
responsibility in ensuring that the already enacted laws yield the enshrined objectives and country fulfils its mandated responsibility under the United Nations Sustainable Development Goals by 2030 when it could not achieve by 2015 .

Cite this article as:

Anand R. National Girl Child Day: Save Girl Child and Educate Her (Guest

Editorial). Int Healthc Res J. 2018;2(10):235-236. doi 10.26440/ihrj.v2i10.192

For article enquiry/author contact details, e-mail at: manuscriptenquiry.ihri@gmail.com 